\title{
A Model of Learning of Intelligent Characters In Higher Education
}

\author{
Famahato Lase, Herman Nirwana, Neviyarni, Marjohan \\ Universitas Negeri Padang \\ famstemos@gmail.com
}

\begin{abstract}
The intelligent character education is a system of values cultivation for the students which encompasses the components of knowledge, awareness, willingness, actions to implement these values and as a way of adjusting the behaviors of the students, in order to become good citizens of the future. These students were being instructed, guided, and toward having some sets of prescribed behaviors, as an explicit learning process from which students in a school community understand, accept, and act on ethical values such as respect for others, justice, civic virtue and citizenship, and responsibility for self and others. To build these characters, it requires a learning model, namely, the Intelligent character learning model. This study aimed at generating a valid, practical and effective model of Learning of Intelligent Characters (LIC) in Higher Education. Research design used was Research \& Development equipped with the five cyclical phases of Analysis, Design, Development, Implementation and Evaluation (ADDIE). In conclusion, the learning of the intelligent character has significant contributions to the academic achievement, behavior, self-esteem, soft skills, morality as well as various other academic characters and achievements.
\end{abstract}

Keywords--education, building character, higher education

\section{INTRODUCTION}

The character education was first coined by German pedagogue F.W. Foerster (1869-1966 which emphasized the ethical-spiritual dimension in the process of personal formation. This study emerged as a reaction to the stagnancy of Rousseauian natural pedagogy and pedagogical instrumentalism Deweyan and pederogical pedagogy through the celebration of the spontaneity of children (Edouard Claparéde, Ovide Decroly, Maria Montessori) colouring pedagogy in Europe and the United States in the early $19^{\text {th }}$-century (Hadi, 2015).

In Indonesia education context, the character education has long been proclaimed since 1947, simultaneously the beginning of the implementation of curriculum system with the vision and mission of characters-based education that prioritized the character education, state and community awareness. In 1964, its development focused on creativity, taste, intention, work, and morals (Pancawardhana). The changes occurred in 1952, 1964, 1968, 1975, 1984, 1994, 2004, 2006 to 2013. The subjects were classified into five groups of subjects, namely, moral, intelligence, emotional/artistic, skill and physical (Kaimuddin, 2013).

The character education is not separated from educational activities and its curriculum is not separated but the spirit of education itself covers the whole process of education from planning, the process to the results obtained. Because wherever education is done, the values will emerge by itself. Studies concluded that the character learning improved the academic achievement, positive behaviour, self-esteem, soft skill and morality as well as various other characters and achievements.

The results of the studies (Benninga, 2003) concluded that the application of character teaching to 681 elementary schools in California over a four-year period showed a positive correlation with a very different learning outcome, ie, if the application of character learning was higher, then the learning outcomes of the learners were the higher too. Character-based learning can improve academic achievement (Parkay, 2010). In Nigeria, Elizabeth (2015) concluded that character building is as important as raising the standard and quality of learning to seek the academic excellence among college students. In Muradiye Manisa (Pala, 2011), character education is an important part of the academic success of learners. It can be concluded that character learning has a very important contribution to academic achievement and recommended to be applied in higher education.

The results of reviews of 261 articles (Chiara, 2016) published in 145 selected academic journals of Education, ERIC, Psychology and Behavioral Sciences during the period 2005-2014 showed that the main trends of the International literature are character education categories. While in Lebanon, Najah (2015) recommended reforming the character education in public schools. In Rome Italy, (Sölay, 2013) concludes that the mission of higher education is not only science but character education to help the community ensure a better and more moral future. In the center of Eskişehir Turkey (Çubukçu, 2012), the results of research conducted on 40 Primary, Grade 6, 7 and 8 Elementary School students from three schools in the 2009-2010 academic year stated that the utmost usefulness of the values contained in the curriculum and the activities of its hidden curriculum advocates in the process of acquiring and internalizing values. In Manisa Turkey, Pala (2011), emphasized the need to guide the learners to know, pay attention 
and act on core ethical values such as respect, responsibility, honesty, justice, compassion and others to help them develop good character.

Character education also has a major impact on behaviour. The results of the study in Memphis USA, (Kinkopf, 2016), concluded that learning character development and ethics in the classroom raises the positive behaviour of learners. While in Purwokerto Indonesia (Najmudin, 2011), the morale of students who follow the ethics class is better than those who have not yet taken it and in Jakarta (Sardjijo, 2017), it is recommended that in the learning, it needs to be selected and determined character types to be integrated into the syllabuses. In Pekuncen (Rukhul, 2014), character education is very important in shaping the affective aspect of learners and strengthening the character of honesty, personality, intelligence and creativity. In Lampung (Brojonegoro, 2016), the application of moral reasoning model is more effective in improving students' morality. In Taiwan (Lee, 2014), there is a positive change in the social interaction and behaviours of learners when the six core values of personal character are incorporated into learning, namely, the character: caring and ignoring others, assessing courage, cooperation, respect, responsibility and honesty. In Bulgarian Sophia (Dodds, 2015), after being given an understanding of the character's values, there is a decrease in the negative behaviour of learners as a whole. It can be concluded that character learning has a very large contribution to student's behaviour.

Character learning also affects self-esteem and soft skills. The research results in Kuwait (Tannir, 2013), concluded that there was a significant difference, ie groups that were taught by character learning higher in self-esteem rank than those taught by traditional learning. In Bali Indonesia (Wijana, 2015:), the integration of character education into the subject matter can improve student soft skills. In Padua Italy (Chiara, 2016), character education plays an important role in building the child's balance and youth identity and can be a special intervention for youth education and their social intercourse. While in North Korea (Hyungsook, 2014), social art practices encourage learners to promote creativity, a sense of responsibility for citizens, critical thinking, reflection, interest in social justice, consideration of people living in the local community and all contribute significantly to character education.

In conjunction to the results of the research, the purpose of this study is to produce a product that has not existed is a model of Learning Character in Higher Education is valid, effective and practical. Research type used is Research \& Development with the five cyclical phases of Analysis, Design, Development, Implementation and Evaluation.

\section{METHODS}

The word character in ancient Greek means "to engrave," which emphasizes the engraved traits will affect us to behave in certain manners. Good character is a concept which contains knowing good, embracing good and doing well (Katilmis, 2011) which refers to a series of attitudes, behaviours, motivations, and skills as well as the rules of good and bad measure of an attitude, and action (Mujtahid, 2016). The character is the nature of psychology, morality or character that characterizes a person or a group of people, something that qualifies a person, becomes identity, traits and properties are fixed (Adisusilo, 2012). Intelligent, on the other hand, perfect the development of his mind to think, understand and sharp mind, clever, healthy, strong growth of his body and the ability to manipulate the elements of the conditions faced to successfully achieve the goal (Prayitno, 2011).

Character and intelligent are the two words combined into one meaning of character, morals attached to the person of someone formed from the results of internalization that is used as a basis for thinking and behaving so as to give a characteristic to the individual, which will develop well if gaining the proper reinforcement of education (Maunah, 2015). People of good character as well as do the good, love and do the good ones (Pala, 2011). Components are moral knowing, moral feeling and moral action that children need to be able to understand, feel and work the values of virtue (Lickona, 2012).

The character is also the possession of good things that are divided into two sides, the right behaviour in relation to self and life full of other people-oriented virtues, such as justice, honesty, gratitude and love (Lickona, 2012). Itis a relatively stable personal trait in the individual that forms the basis for his behaviour in high standards and norms (Prayitno, 2011) and as the embodiment of realizing life through right actions in relation to oneself and others (Sigit, 2013). These characters need to be integrated into all subjects/lectures (Nanik, 2016).

\section{Educating the intelligent character and Culture of the Nation}

Building character means building a truly sincere, systematic and sustainable future and there is no better future can be realized without honesty, enhancing self-discipline, persistence, high learning spirit, developing a sense of responsibility, fostering unity in the middle diversity, enthusiasm contribute to common progress, as well as confidence and optimism (Farida, 2012).

The intelligent character is a system of values to the learners that includes the components of knowledge, awareness, willingness, action to carry out those values and as a way of adjusting the behaviors of the students, in order to become good citizens of the future. These students were being instructed, guided, and toward having some sets of prescribed behaviors (Agboola, 2012), as an explicit learning process from which students in a school community 
understand, accept, and act on ethical values such as respect for others, justice, civic virtue and citizenship, and responsibility for self and others (U.S. Department of Education, 2005).

Tannir (2013, p. 1) stated, "Character education is a developmental curriculum aimed at teaching learners to make knowledgeable and responsible choices by acquiring the knowledge, skills, and abilities needed, focus on social, emotional and personal development; children learn to value themselves, respect others, be responsible, cooperate with other individuals, solve problems, be honest and trustworthy." Therefore, it needs to be based on the rules of scientific theory, that is, the education of education and implemented with the plan and preparation according to the praxis applicable and available, practiced effectively and efficiently which also according to the planning and preparation by taking into account the actual condition that exist (Prayitno, 2011).

There are nine characters derived from universal values, namely, the character of God's love and all of His creation, independence and responsibility, honesty/ diplomacy, respect and courtesy, generous, helpful and cooperative, and hard work, leadership and justice, good and humble, and the character of tolerance, peace and unity (Azzmardi, 2002). Other values that need to be taught to learners are: honesty, loyalty and dependability, respect, love, selfishness and sensitivity, kindness and companionship, courage, peace, independence and potential, discipline and moderation, loyalty and purity and justice and affection (Mansyur, 2011). While the orientation of true education is the main door and first in building a personality or human character (Kaimuddin, 2013). It means that raising children as insightful, caring, high-minded, righteous people and individuals who use their best capacity to do their best, and who understand the purpose of life. It also helps children to get to know and desire for the good and engaged in good actions eventually (Turan, 2016).

\section{FINDING AND DISCUSSION}

The product produced in this research is a valid, effective and effective character intelligence learning model that can be used as a learning model for all courses. This model is designed in accordance with the function and objectives of the National Education of Indonesia is "developing and forming the character and civilization of a dignified nation in order to educate the nation's life, aims for the development of potential learners in order to become a man of faith and cautious to God Almighty, noble, healthy, knowledgeable, capable, creative, independent and become a democratic and responsible citizen "(Law No. 20 of 2003).

This objective is a formulation of the quality of Indonesian people that must be developed by each educational unit in accordance with the culture and character of the nation. The sources of education are: Religion, Pancasila (The Five Pillars), Culture and national education objectives, namely values: religious, honest, tolerance, discipline, hard work, creative, independent, curiosity, spirit of nationalism, love of the country, appreciate achievement, friendly / communicative, love peace, love to read, care about the environment, social care, and responsibility (Rayon, 2010).

\section{Education of Intelligent Character in Higher Education Teacher/ Lecturer's Roles}

The core of college activities is Higher Education's Tridharma as the main task of a lecturer that is all educational activities, research and community service performed with character (Santoso, 2013). Lecturers become the main actors in shaping and developing the character of students with exemplary in carrying out this main task. He has a good image in society because it can show his proper attitude to be a role model for society (Redjeki, 2015). This study is done through the habituation of everyday life and become a campus culture (Masan, 2013). In addition to sorting out other positive cultural values of the nation and filter them into human character and Indonesian citizens fully noble character, intellectual and dignified (Rukiyati, 2014, Wibowo, 2013).

Lecturers are educators who give knowledge to students in universities, have experience in the profession and the knowledge they have can form them to be intelligent and broad-minded (Eva, 2015). Therefore, students are the center of the educational enterprise, and their cognitive and affective learning experiences should guide all decisions as to what is done and how (Brown, 2011). Each university should have a pattern of character formation of students in accordance with its vision, mission, characteristic (Eva, 2015), especially forming intellectual resources that can contribute to the nation such as politics, law, economics, education, health, religion and others which can improve the lives and welfare of the community.

\section{Character of the lecturer}

The characters of a lecturer are to have the commitment, competent, hard work, consistent, simple, have ability to interact, serve maximally, intelligent, sincerity in work, self and honor, become role model for learners, have vision, of his duties and calls. There are six dimensions of lecturer character which is universal according to UNESCO, that is: trustworthiness, respect, responsibility, fairness, caring, citizenship (Masan, 2013).

This character is the main capital for lecturers to conduct intelligent character learning in universities, so before educating students in intelligent characters must first have the character (Syukri, 2017), so it can open the eyes of the students to learn and be able to live with the values of the intelligent character in their community. 


\section{Integrating the Values of Intelligent Character}

Integrating the values of intelligent characters in teaching and learning process may vary, tailored to the characteristics of the course or other emphases (Sukidjo, 2013). Aspects of the target characters are obedience of worship, honesty, responsibility, caring, cooperation, hard work and respect for others. Of these intelligent characters, values can be selected at least one aspect that corresponds to the characteristics of each course.

There are three steps that need to be done in the learning of intelligent characters, namely: the identification of values, value learning and opportunity to apply those values. Showing moral behavior that has a stronger impact than speaking about morals is the same as One man practicing good sportsmanship is better than fifty others preaching it. Therefore, students need to know what is allowed and should not be done. That is, there is a common understanding related to moral behaviour; explain and discuss moral behaviour; using and teaching ethics in decision making (Winarni, 2013).

\section{CONCLUSION}

Referring to the preliminary studies and theoretical studies, it can be concluded that 1) building the character is like as building a truly, systematic and sustainable future of the students; 2) if education merely oriented to the cognitive, psychomotor domains and ignored the affective domain, which only pushed them to rationally think of without moral education is like as building a threat in social life. They are intelligent, know a lot about something, but do not have the attitude, interests, value system or positive appreciation of what they know, they are still labeled as uncharacterized individuals; 3) the values of intelligent characters need to be integrated into all subjects/lectures; 4) Intelligent character education is a system of values for the students that incorporates the components of knowledge, awareness, willingness, actions to implement these values and as a way of adjusting the behaviors of the students, in order to become good citizens; and 5) intelligent character learning has a very large contribution to: academic achievement, behavior, increased self-esteem, soft skills and morality as well as various characters and other academic achievements.

\section{References}

Adisusilo, S. (2014). Pembelajaran nilai-nilai karakter: Kontruktivisme dan VCT sebagai inovasi pendekatan pembelajaran afektif. Jakarta: Raja Grafindo Persada.

Agboola, A. \& Kaun, C.T. (2012). Bring Character education into classroom. European Journal Of Educational Research, 1(2), 163-170. Retrieved from http:// files. eric. ed. gov.

Azzmardi, A. (2002). Paradigma Baru Pendidikan Nasional Rekonstruksi dan Demokratisasi. Jakarta: Kompas.

Benninga, J.S., Marvin W. Berkowitz, P.K. \& Karen, S. (2003). The relationship of character education. implementation and academic achievement in elementary schools. Journal of Research in Character Education, 1(1), 19-32. Retrieved from http:// www. csufresno. edu/ kremen/ bonner center

Brojonegoro, Soemantri, Mukino, Edi, P. \& Irawan, S. (2016). Penerapan model moral reasoning untuk membentuk moralitas dan karakter siswa pada PKn. Jurnal Studi Sosial 4(1). Retrieved from https: //media. neliti. com/ media/ publications.

Brown, A. \& Timothy, G.D. (2011). The essentials of instructional design: Connecting fundamental principles with prosess and practice. Boston: Pearson.

Chiara, P. (2016). Character education: Themes and researches. an academic literature review. Character Education C. Pattaro Italian Journal Of Sociology Of Education, 8 (1). Retrieved from http://ijse. padovauniversitypress. it/ system.

Çubukçu, Z. (2012). The effect of hidden curriculum on character education process of primary school students. Journal, Educational Sciences: Theory \& practice. [Online]. Retrieved from http:// www. kuyeb. com.

Dodds, D.M.. (2015). The effects of character education on social emotional behavior. Journal. St. Catherine University Sophia, 11. Retrieved from https:// sophia. stkate. edu/ cgi.

Elizabeth, O., Amos, A.A., \& Jonathan, O.A. (2015). Time management practices, character development and academic performance among university undergraduates: Covenant university experience. Journal, Creative Education, 6, 79-86. Retrieved from http:// creativecommons. Org.

Eva, M.R. (2015). Urgensi Pendidikan Karakter di Perguruan Tinggi. Jurnal Pendidikan Ilmu-Ilmu Sosial 7(1), $49-59$. Retrieved from http:// jurnal. unimed. ac. id.

Farida, I. (2012). Model pendidikan karakter di perguruan tinggi: Langkah strategis dan implementasinya di universitas. Jurnal Ilmiah Administrasi Publik dan Pembangunan, 3(1). Retrieved from http:// download. portalgaruda. org.

Hadi, S. (2015). Menggagas pendidikan karakter responsif gender. Jurnal Palastren 8(2). Retrieved from http:// download. portalgaruda. org/ article.

Hyungsook, K. (2014). Socially engaged art practice and character education: understanding others through visual art. International Journal of Education Through Art, 10(1), 55-69. Retrieved from http://www. ingentaconnect. com. 
Kaimuddin, (2013). Implementasi pendidikan karakter dalam kurikulum 2013. Jurnal Dinamika Ilmu, 14(1). Retrieved from http:// journal. iain- samarinda. ac. id.

Katilmis, A., Eksi, H. \& Öztürk, C. (2011). Efficiency of social studies integrated character education program. Academic Journal Article Kuram Ve Uygulamada Egitim Bilimleri. Retrieved from https: //www. questia. com/library/ journal.

Kinkopf., Timothy, W. \& Cort, C. (2016). Character education: Teachers' perceptions of its implementation in the classroom. Delta State University Journal of Education, 6(1). Retrieved from http:// www. deltastate. Edu.

Lee, A. (2014). Implementing character education program through music and integrated activities in early childhood settings in Taiwan. International Journal of Music Education. Retrieved from http:// journals. sagepub. com/doi.

Lickona, T. (2012. Character matters. Jakarta: Bumi Aksara.

Mansyur, M. (2011). Pendidikan karakter, menjawab tantangan krisis multi dimensional. Jakarta: Bumi Aksara.

Masan, M.B. (2013). Peran dosen dalam mengembangkan karakter mahasiswa. Jurnal Humaniora, 4(2), 800-810. Retrieved from http:// research- dashboard. binus. ac. id.

Maunah, B. (2015. Implementasi pendidikan karakter dalam pembentukan kepribadian holistik siswa. Jurnal Pendidikan Karakter, 5(1). Retrieved from http:// www. tappdf. com/ journal-uny.

Mujtahid. (2016). Model implementasi pendidikan karakter melalui pendekatan terintegrasi dalam perkuliahan pada jurusan PAI-FITK UIN Maulana Malik Ibrahim Malang. Jurnal Ulul Albab 17(2). Retrieved from http:// repository. uin- malang. ac. id.

Najah., Ghamrawi A. R., Ghamrawi, N. \& Shal, T. (2015). Perception of character education: The Case of Lebanese School Leaders. Open Journal of Leadership, 4, 129-142. Retrieved froam https:// file. scirp. org.

Najmudin. (2011). Studi tentang intervensi etika dan peningkatan moral mahasiswa. Jurnal Bisnis dan Ekonomi (JBE), 18(1), 69-83. Retrieved from https:// media. neliti. com/ media/ publications.

Nanik, M. (2016). developing students' intelligent character through linguistic politeness: The case of english as a foreign language for Indonesian students. International Journal, English Language Teaching, 9(1). Canadian Center of Science and Education. Retrieved from http:// files. eric. ed. gov.

Pala, A. (2011). The need for character education. International Journal Of Social Sciences And Humanity Studies, 3(2). Retrieved from http:// sobiad. org/ ejournals.

Parkay, F.W., Glen., H.J. \& Erci, A.J. (2010). Curriculum Leardership: Readings for developing quality educational programs. Boston: Pearson.

Prayitno., \& Aktiva, K. (2011). Butir-butir nilai karakter cerdas dalam kandungan pancasila serta kehidupan yang utuh dan efektif. Padang: Universitas Negeri Padang.

Rayon 140. (2010). Modul PLPG Guru Kelas Sekolah Dasar. Purwokerto: UMP.

Redjeki, S. (2015). Pengembangan profesionalisme dosen dan inovasi pembelajaran. Jurnal Majalah Ilmiah Pawiyatan 12(3). Retrieved from http://e-journal. ikip- veteran. ac. id.

Rukhul, A.H., Suhartono. \& Joharman. (2014). Implementasi pendidikan karakter dalam pembentukan ranah afektif kejujuran dalam kehidupan sosial siswa kelas V SDN Pekuncen Tahun Pelajaran 2013/ 2014. Jurnal FKIP Universitas Sebelas Maret. Retrieved from http:// jurnal. fkip. uns. ac. id.

Rukiyati., N. Sutarini, Y.C. \& Priyoyuwono, P. (2014). Penanaman nilai karakter tanggung jawab dan kerja sama terintegrasi dalam perkuliahan ilmu pendidikan. Jurnal Pendidikan Karakter, 4(2). Retrieved froam https:// media. neliti. com.

Santoso. (2013). Materi ajar mata kuliah pendidikian Pancasila. Jakarta: Kenediknas RI.

Sardjijo \& Hapzi, A. (2017). Integrating character building into mathematics and science courses in elementary school. International Journal Of Environmental \& Science Education, 12(6), 1547-1552. Retrieved from www. ijese. net/ makale - indir.

Sigit, M.W. (2013). pembelajaran kontruktivisme, teori dan aplikasi pembelajaran dalam pembentukan karakter. Bandung: Alfa Beta.

Sölay, N. (2013). A Survey of values education and its connection with character education. Academic Journal of Interdisciplinary Studies MCSER Publishing, Rome-Italy, 2(3). Retrieved from http:// citeseerx. ist. psu.edu.

Sukidjo, A.M., Mustofa., \& Maimun, S. (2013). Pengembangan character building dengan contextual teaching and learning dalam pembelajaran perpajakan di jurusan pendidikan ekonomi Fakultas Ekonomi Universitas Negeri Yogyakarta. Jurnal Pendidikan, 22(1). Retrieved from http:// staffnew. uny. ac. id.

Syukri, D.A., \& Alaren. (2017). Peran dosen dalam mengembangkan karakter mahasiswa. Jurnal Pelangi, 9(2), 88-97. Retrieved from http:// dx. doi. org.

Tannir, A. \& Anies, A. (2013). Effects of character education on the self-esteem of intellectually able and less able elementary students in kuwait. International Journal of Special Education, 28(2). Retrieved from www. international journal of specialed.com.

Turan, F. \& Ilkay, U. (2016). Using storybooks as a character education tools. Journal of Education and Practice,.7(15). Retrieved from http:// files. eric. ed. Gov. 
UU [Law] RI No 20 tahun (2003), Tentang sistem pendidikan nasional-UUSPN).

U.S. Department of Education. (2005). Character education . . our shared responsibility [Brochure]. Retrieved from http:// www. ed. gov/ admins/ lead/ character/ brochure. pdf.

Wibowo A. (2013). Pendidikan karakter di perguruan tinggi dan membangun karakter ideal mahasiswa. Yogyakarta: Pustaka Pelajar.

Wijana, N. (2015). Pengaruh Pengintegrasian Pendidikan Karakter Berorientasi Kearifan Lokal ke dalam Materi Ajar Mata Kuliah Ilmu Lingkungan untuk Meningkatkan Soft Skill Mahasiswa. Jurnal Pendidikan Indonesia, 4(2). Retrieved from https:// ejournal. undiksha. ac. id.

Winarni, S. (2013). Integrasi pendidikan karakter dalam perkuliahan. Jurnal Pendidikan Karakter, 3(1). Retrieved from www. undana. ac. id. 